\title{
Determination and Comparison of Elementary Science, Primary Classroom and Preschool Teacher Candidates' Environmental Attitude Levels Serap ÖZ AYDIN ${ }^{1,}{ }^{*}$, Selin ŞAHİN ${ }^{1}$, Taner KORKMAZ ${ }^{2}$ \\ ${ }^{1}$ Balıkesir University, Balıkesir, TURKEY; ${ }^{2}$ Ministry of Education, Ankara, TURKEY
}

Received: 05.09.2012

Accepted: 30.10 .2013

Abstract: Formation and solution of environmental problems, which have economy, politics and education depends on the mentality and attitudes. This study is carried out to determine and determine the behavior and attitude dimensions of teacher candidates from different branches toward environment. The sample of the study consisted of elementary science, primary classroom and preschool education students attending the first and fifth terms of the program . Environmental Attitudes Survey (EAS) was administered to the teacher candidates. The responses of the teacher candidates were analyzed using SPSS 16 software and the education programs content of each department were analyzed to reason differences among the departments. It was revealed that science teacher candidates' means of environmental attitudes are the highest of all. However, when comparing the first and fifth term students' mean scores, it is interesting that first term preschool teacher candidates and first term primary classroom teacher candidates' EAS mean scores are higher than those of fifth term students. These results point out that it is required to consider important environmental education in higher education.

Key words: Environmental education, environmental attitude, elementary science education, primary education, preschool education

DOI No: http://dx.doi.org/10.12973/nefmed209

\section{Summary}

Introduction: Creation and solution of environmental problems, which have economy, politics and education dimensions depend on the mentality and attitudes. According to the "Re-Orienting Teacher Education for Sustainability" guidelines prepared by UNESCO (2005) "Education for Sustainable Development Education" can only be attained by not receiving

\footnotetext{
* Corresponding author: Assist. Prof. Dr., Necatibey Faculty of Education, Balıkesir University, 10100, Balıkesir/TURKEY.

E-mail: ozaydinserap@gmail.com
} 
information passively and understanding the subjects but developing skills, attitudes, values and understanding about that subject. This study is carried out to determine the behavior and attitude dimensions of teacher candidates from different branches toward environment.

Methodology: The study was conducted using cross-sectional survey design. The population of the study consisted of teacher candidates attending the departments of Elementary Science Education, Primary Education, and Early Childhood Education at Necatibey Faculty of Education at Balıkesir University. The data were collected from the sample consisted of 161 $1^{\text {st }}$ and $3^{\text {rd }}$ year students attending these departments in fall semester of 2009-2010 academic year. The data collection tool for the study was a scale developed by Uzun and Sağlam (2006) made up from a 13-item part measuring environmental attitudes' behavior and a 14-item part measuring environmental attitudes' mental dimensions. The attitude scores obtained from the scale were analyzed using independent samples t-test, one-way ANOVA and Tukey post hoc test, embedded in SPSS, to determine the sources of differences. Cronbach's alpha internal consistency coefficient of the scale was calculated as 0.873 . To make healthier interpretations from the results of these analyses curricula of elementary science, primary and early childhood education departments were examined in order to find out whether there are any courses including subjects related to environment (YÖK, 2012).

Conclusion-Discussion: Participant elementary science teacher candidates had the highest environmental attitude mean score of 103.26, while preschool teacher candidates received the lowest score of 92.87. Primary school classroom teachers' environmental attitude mean score was determined as 100.46 . With this study it was determined that teacher candidates' environmental attitude levels were incompetent. Evaluating the teacher candidates' environmental attitude levels on the gender basis, it was observed that there is variation depending on the sampling. On this basis gender is not a distinguishing factor. Comparing the teacher candidate attitudes' mind and behavior dimensions, it was seen that the mind dimension was superior to the behavior dimension. Comparing the teacher candidates' environmental attitudes according to the class levels, $1^{\text {st }}$ year students of primary classroom and preschool teacher candidates' attitude levels toward environment were found to be higher than those of $3^{\text {rd }}$ year students'. This finding is rather thought provoking.

Including courses containing subjects of nature and environment in Early Childhood Education departments' curriculum and adding some elective courses about nature and environment to the Primary Education curriculum may lead to development of positive attitudes toward nature and environment. Additionally, environment education is an activity 
that should be continued lifelong. Teacher candidates should be supported for taking part and accepting duty in non-governmental organizations in order to help them increase their environmental attitude levels and participation skills. 


\title{
İlköğretim Fen Bilgisi, Sınıf ve Okul Öncesi Öğretmen Adaylarının Çevresel Tutum Düzeylerinin Belirlenmesi ve Karşılaştırılması
}

Serap ÖZ AYDIN ${ }^{1,+}$, Selin ŞAHİN ${ }^{1}$, Taner KORKMAZ ${ }^{2}$

\author{
${ }^{1}$ Balıkesir Üniversitesi, Balıkesir, TÜRKIYYE; ${ }^{2}$ Milli Eğitim Bakanlığı, TÜRKİYE \\ Makale Gönderme Tarihi: 05092012 \\ Makale Kabul Tarihi: 00 Ay 2013
}

\begin{abstract}
Özet: Çevre sorunlarının oluşumu ve çözümü ekonomi, siyaset ve eğitimdeki anlayış ve tutumlara bağlıdır. Bu çalışma, farklı alanlardaki ilköğretim öğretmen adaylarının çevreye yönelik tutumlarının davranış ve düşünce boyutlarını tespit etmeye ve karşılaştırmaya yönelik olarak yapılmıştır. Araştırmanın örneklemi Balıkesir Üniversitesi Necatibey Eğitim Fakültesi İlköğretim Bölümü Fen Bilgisi Öğretmenliği, Sınıf Öğretmenliği ve Okul Öncesi Öğretmenliği Ana Bilim Dallarının 1. ve 5. döneminde okuyan 161 öğretmen adayından oluşmaktadır. Öğretmen adaylarına çevresel tutum ölçeği uygulanmıştır. Öğretmen adaylarının ankete verdikleri cevaplar SPSS-16 programı ile analiz edilmiş ve alanlar arasındaki farkların nedenini açıklayabilmek için her ana bilim dalındaki dersler ve içerikleri incelenmiştir. Öğretmen adaylarının çevreye yönelik tutumlarının genel ortalamasına bakıldığında fen bilgisi öğretmen adaylarının sınıf öğretmenliği ve okul öncesi öğretmen adaylarına göre daha iyi düzeyde olduğu tespit edilmiştir. Bunun yanında öğretmen adaylarının 1. ve 3. sınıf düzeyinde karşılaştırılmalarında okul öncesi ve sınıf öğretmenliği öğretmen adaylarının 1. sınıf çevresel tutum puanlarının ortalamalarının 3. sınıf çevresel tutum puanlarının ortalamalarına göre daha iyi düzeyde olması ilgi çekicidir. Bu durum lisans eğitiminde çevre eğitimine verilmesi gereken önemi ön planda tutmamızın gerekliliğini göstermektedir.

Anahtar kelimeler: Çevre eğitimi, çevresel tutum, ilköğretim fen eğitimi, sınıf öğretmenliği eğitimi, okul öncesi eğitimi
\end{abstract}

\footnotetext{
${ }^{\dagger}$ İletişim: Serap Öz Aydın, Yrd. Doç. Dr., İlköğretim Bölümü, Fen Bilgisi Eğitimi Anabilim Dalı, Necatibey Eğitim Fak., Balıkesir Üniversitesi, 10100, Balıkesir, TÜRKIYE.

E-mail: ozaydinserap@gmail.com
} 


\section{Giriş}

Çevre "bir canlı organizmayı veya bir canlı topluluğu yaşamı süresince etkileyen her türlü, biyotik ve abiyotik (sosyal, kültürel, tarihsel, iklimsel, fiziksel) faktörlerin tümü" olarak tanımlanmaktadır (Yücel ve Morgil, 1999). Canlı yaşamı, içinde bulunduğu ortamın bir ürünü olduğundan çevrenin, doğal ya da çeşitli müdahalelerle değişmesi o bölgede bulunan tüm canlılık faaliyetlerini de aynı oranda etkilemektedir (UNESCO-UNEP,1987). Uzun yıllar çevresi ile uyumlu ve bir bütün halinde bir yaşam sürdüren canlılar açısından çevre sorun olmamıştır. Ancak insanlar üzerinde yaşadığı dünyayı kontrol altına alma ve ona egemen olma hırsı ve gururu içinde yaşadıkları dünyayı kendi istek ve yararları doğrultusunda değiştirmişler ve değiştirmeye devam etmektedirler (Çepel, 2003). Sanayileşme ile başlayan bugünkü ekonomik sistemlerin sınırsız büyüme ve refah artışı amaçlarını gerçekleştirmek adına dünya kaynaklarının kayıtsızca tüketilmesine ve yüksek miktarlarda atık üretilmesine sebep olduğu 1970' lere kadar insanlık tarafından önemsenmemiştir. Ancak bu dönem başından itibaren Aydoğdu ve Gezer (2006) tarafından da belirtildiği gibi hızla artan dünya nüfusuyla birlikte, hızlı sanayileşme ve sağlıksız kentleşme, nükleer denemeler, tarım ilaçları, yapay gübreler, deterjanlar gibi kimyasal maddelerin giderek çevreyi kirletmeye başlaması şeklinde karşımıza çıkmakta, bunun sonucu olarak kirlenen hava, su ve toprak, canlılar için zararlı olabilecek ciddi boyutlara ulaşmaktadır. $\mathrm{Bu}$ kirlilik "çevre sorunu” olarak ele alınmaktadır. Bu sorunların giderek şiddetlenmesiyle çevre ile ilgili uluslararası çalışmalar ortaya çıkmaya başlamıştır. Çevre ve eğitim sözcükleri ilk kez 1960'ların ortasında birlikte kullanılmaya başlanmıştır. Özellikle Carson (1962) tarafından yazılan Silent Spring ve Schumacher (1973)'in Small is Beatiful adlı kitapları batı toplumlarının çevre anlayışları üzerinde son derece etkili olmuştur. $\mathrm{Bu}$ konuda 1972 yılında yapılan Stockholm Konferansı'nda “tek bir dünyamız var” sloganı ortaya çıkmıştır (UNEP, 1972). Vatandaşları, toplumu çevreyle ilgili konularda bilimsel gerçekler doğrultusunda bilgilendirmek ve çevrenin korunmasına yönelik bilincin oluşmasında bireylerde davranış değişiklikleri yaratmak ve kazandırmak eğitim yoluyla mümkündür. İnsanların çevre bilincini oluşturup davranış olarak sergilemesi ve günlük davranışlarının çevre üzerinde yaratacağı etkiler hakkında bilgi sahibi olması için gerekli olan çevre eğitimidir (Ünal et all., 2001). Çevre eğitiminin öneminin farkına varılmasıyla 1977 Tiflis’te gerçekleştirilen Hükümetler arası Çevre Eğitim Konferansı'nın (ICEE, 1977) kapanışında tüm katılımcıların kabul etmesiyle ortaya konan metinde çevre eğitiminin amaçları belirlenmiştir (Hungerford et all., 1994). 
- Bilinç: Bireylerin ve toplumların tüm çevre ve sorunları hakkında bilinç ve duyarlık kazanmasını sağlamak;

- Bilgi: Bireylerin ve toplumların çevre ve sorunları hakkında temel bilgi ve deneyim sahibi olmalarını sağlamak;

- Tutum: Bireylerin ve toplumların çevre için belli değer yargılarını ve duyarlılığını, çevreyi koruma ve iyileştirme yönünde etkin katılım isteğini kazanmalarını sağlamak;

- Beceri: Bireylerin ve toplumların çevresel sorunları tanımlamaları ve çözümlemeleri için beceri kazanmalarını sağlamak

- Katılım: Bireylere ve toplumlara, çevre sorunlarına çözüm getirme çalışmalarına her seviyeden aktif olarak katılma olanağı sağlamak.

Ancak her çevre eğitimi bu amaçlara ulaşmada başarılı olamamaktadır. Günümüzde çeşitli kıyamet senaryoları üretilirken Avrupa ülkelerinin başı çektiği bir çok ülke insanlığın sağlıklı çevrelerde hayatlarını devam ettirebilmelerini sağlamak amacıyla bir çok çalışma yapmaktadır. Yapılan bu çalışmalar için büyük bütçeler ayrılmaktadır. Ancak bu çalışmaların başarılı olması için bireylere önemli görevler düşmektedir. Bu görevlerin farkında olma ve çevre bilinci kazanma ise ancak etkili bir çevre eğitimi ile sağlanabilir (Alım, 2006).

İlköğretim programlarının revize edilip yapılandırmacı yaklaşımla düzenlenmesiyle çevre eğitiminin verimliliği açısından önemli adımlar atılmıştır. Yeni ilköğretim programlarında çevre konuları, Hayat Bilgisi, Sosyal Bilgiler ile Fen Ve Teknoloji programlarında oldukça geniş yer tutmaktadır (Alım, 2006). Pooley ve O’Connor (2000) tarafından ders programlarının değerlendirildiği çalışmada, programlarda tutum ve davranış boyutunun ihmal edildiği, programların daha çok bilgi verme hedefi olduğu ortaya çıkarılmıştır. Yine kendilerinin belirttiği gibi çevre eğitimi programları çevreyle ilgili kavramasal bilginin artmasıyla birlikte çevre davranışını geliştirmeye doğru değişmektedir (Pooley ve O'Connor, 2000). Tanrıverdi' nin 2009' da ilköğretim programlarının kazanımlarıyla ilgili olarak çoğunluğunun bilgi ve tutum geliştirmeye yönelik, çok azının beceri, anlayış ve değer geliştirmeye yönelik olduğunu söylemektedir. Ayrıca programların sürdürülebilir çevre eğitimi anlayışıyla değil çevre koruma anlayışıyla hazırlandığı belirtilmektedir. Yine Ayvaz (1998)'e göre ilköğretimde çevre eğitiminin amacı, çocuklara teorik bilgiler yüklemek değil, çevrenin ve çevre sorunlarının farkına varmalarını sağlamak olmalıdır. MEB Okul Öncesi Eğitim Programı genel olarak incelendiğinde, çevre eğitimine 
yönelik amaç, kazanım, kavramların düzeyinin az olduğu görülmektedir (Gülay ve Ekici, 2010). Birbiriyle bağlantılı, öğrenci merkezli ve bol etkinlikle verilecek konuların öğrenciler tarafından davranışa dönüştürülmesi şüphesiz daha kolay olacaktır.

Ancak öğretim programlarının başarısında öğretim sürecindeki diğer faktörlerin önemi unutulmamalıdır (Alım, 2006). Çevre eğitiminin hedefine ulaşmasındaki en önemli faktör ise öğretmendir (IEEP 1994). Öğretmenin kullandığı programın dayandığı ilkeleri doğru anlaması ve uygulamalarını buna göre yapması eğitimin amaçlarının gerçekleştirilebilmesi açısından temel davranışlardır. Ayrıca çevre eğitiminde ne kadar mükemmel programlar hazırlarsanız hazırlayın bu programı uygulayacak öğretmenlerin de çevreye duyarlı, çevre eğitiminin gerekliliğine inanan, bu konuda yeterli bilgi ve beceriye sahip ayrıca istekli olmaları gerekir. Öğretmen çevre konusunda öğrenci için iyi bir model olmalıdır (Şimşekli, 2004). UNESCO (2005) tarafından hazırlanan "Sürdürülebilirlik Açısından Öğretmen Eğitimini Yeniden Planlama Önerileri ve Rehberi”ne göre sürdürülebilir kalkınma için eğitim verilirken bilgiler ve konular pasif olarak verilmek yerine bu konuda beceri, tutum, değer ve tutum geliştirilmelidir. Şama (2003) ya göre çevre eğitiminde başarı için öncelikle çevreye yönelik tutumların nasıl oluştuğu, olumsuz olanların nasıl değiştirilebileceği sorularına cevap verilmelidir. Tutum, bir nesneye ilişkin duygu, düşünce ve davranışlardan oluşmaktadır. $\mathrm{Bu}$ boyutlar birbiriyle ilişkilidir ve birbirlerinden bağımsız değildir. Karşılıklı olarak birbirlerini etkiler, birbirinden etkilenir ve çoğu kez aralarında bir tutarlılık bulunur (Aydın, 2000; Özgüven, 2004). Bir tutum, genellikle bireyi tutum nesnesi ile ilgili davranışlar sergilemeye iter. Bu davranış, olumlu tutuma sahip bireylerde olumlu davranmaya, yaklaşmaya, yakınlık göstermeye, onu desteklemeye yöneliktir. Olumsuz tutum durumunda ise ilgisiz kalma, uzaklaşma, eleştirme, zarar verme gibi davranışlar gözlenmesi olasıdır (Aydın, 2000). Çevre eğitimi konusunda davranış ve tutumların önemi bu konuda yapılan çalışmaların sayısının da artmasını sağlamıştır (Thompson \& Barton, 1994; Worsley \& Skrzypiec, 1998; Eagles \& Demare, 1999; Kaiser et al., 1999a; Şama 2003; Tuncer et all. 2005; Uluçınar et all. 2008; Metin 2010; Şafakl1, 2012).

Çocuk birliği (Childhood Alliance) tarafından yayınlanan raporda çocukluk döneminin doğal dünyaya ilişkin endişe, ilgi, farkındalık, eğitim değer verme ve bilgi kazanma açılarından kritik dönem olduğu ve çevreye yönelik çalışmaların erken yaşlarda başlanmasının önemle gerektiği belirtilmiştir (Cordes ve Miller, 2000). Bu nedenle çevre eğitimi ne kadar erken verilirse o kadar iyidir. Çünkü okul öncesi ve okul dönemlerinde oluşturulabilen ilgi ve tutumlar gelecekteki davranışların temelini oluşturacaktır (De Haan, 
1991). Bu yüzden bu yaşlarda öğrencilere model olan öğretmenlerin çevreye karşı tutum ve davranışlarının çok yüksek seviyede olması beklenir. $\mathrm{Bu}$ nedenle öğretmenlerin çevreye yönelik ne kadar olumlu tutum ve davranışlara sahip olarak yetiştirildikleri de önem kazanmaktadır.

Çevre eğitiminin yaygın eğitimde tüm yaşam boyu devam etmesi gerektiği gibi örgün eğitimde de ilköğretimde bir bütünlük içinde anaokulundan ilköğretim ikinci kademeye kadar kesintisiz olarak devam etmesi gereği açıktır. Ayrı ayrı ilköğretimin üç farklı basamağına ait bir çok çalışma bulunmaktadır (Worsley \& Skrzypiec 1998; Bozkurt, 2004; Şimşekli, 2004; Farmer et all., 2007; Gülay \& Ekici 2010; ) ancak bu çalışma özellikle bu üç ayrı ilköğretim bölümünün bir arada çalışıldığı ve karşılaştırıldığı bir çalışma olması dolayısıyla önemlidir.

$\mathrm{Bu}$ çalışmada ilköğretim fen bilgisi, sınıf öğretmenliği ve okul öncesi öğretmen adaylarının çevresel tutum düzeylerinin belirlenmesi ve karşılaştırılması amaçlanmıştır. Bu amaç kapsamında aşağıda belirtilen sorulara cevap aranmıştır:

1.Okul öncesi, sınıf ve fen bilgisi öğretmen adaylarının çevreye yönelik ortalama tutum puanları nedir ve bölümler arasında çevresel tutum puanlarında anlamlı bir farklılık var midir?

2. Okul öncesi öğretmenliği, sınıf öğretmenliği ve fen bilgisi öğretmen adaylarının;

a) çevresel tutum puanlarında cinsiyete göre anlamlı bir farklılık var mıdır?

b) çevresel tutum puanlarında sınıf değişkenine göre anlamlı bir farklılık var mıdır?

c) çevresel tutum puanlarının düşünce ve davranış boyutları arasında ilişki var mıdır?

\section{Yöntem}

$\mathrm{Bu}$ çalışma kesitsel tarama araştırması şeklinde gerçekleştirilmiştir. Kesitsel tarama araştırmalarında betimlenecek, gelişim özellikleri, okuduğunu anlama becerileri, tutum gibi değişkenler, bir seferde ölçülür (Büyüköztürk ve ark. 2008).

Araştırmanın evrenini Balıkesir Üniversitesi Necatibey Eğitim Fakültesi İlköğretim Bölümü Fen Bilgisi Öğretmenliği, Sınıf Öğretmenliği ve Okul Öncesi Öğretmenliğinde okuyan öğretmen adayları oluşturmaktadır. Örneklem ise bu bölümlerde 2009-2010 eğitimöğretim yılı I. yarıyılındaki birinci ve üçüncü sınıf öğrencilerinden oluşmaktadır. Fen bilgisi öğretmenliği birinci sınıf 40, üçüncü sınıf 21, sınıf öğretmenliği birinci sınıf 48, üçüncü sınıf 21, okul öncesi öğretmenliği birinci sınıf 18, üçüncü sınıf 13 öğrenci olmak üzere toplam 161 öğrenci ile çalışılmıştır. 
Araştırmanın veri toplama aracı Uzun ve Sağlam (2006) tarafından geliştirilen ve Keleş, Uzun ve Uzun (2010) tarafindan öğretmen adaylarının çevresel tutum, düşünce ve davranışlarının belirlenmesinde kullanılan, toplamda 27 maddeden oluşan çevresel tutum ölçeğidir. Bu ölçek çevresel tutumun davranış boyutunu ölçen 13 madde ve çevresel tutumun düşünce boyutunu ölçen 14 maddeden oluşmaktadır. Ölçeğin daha önce yapılan çalışmada Cronbach alfa iç tutarlılık katsayısı 0.80 olarak bulunmuştur.

Verilerin analizinde tutum ölçeği puanları hesaplanırken, cevaplara göre 5 (tamamen katılıyorum), ile 1 (hiç katılmıyorum) arasında değerler verilip, her öğrenciye ait bir çevresel tutum puanı elde edilmiştir. Ölçekten alınabilecek minimum puan 27, maksimum puan ise $135^{\prime}$ tir. Ölçekten elde edilen tutum puanları SPSS programında ilişkisiz t-testi, one-way ANOVA ve farkın hangi gruptan kaynaklandığı belirleyebilmek için çoklu karşılaştırma testlerinden Tukey testi ile analiz edilmiştir. Cronbach alfa iç tutarlılık katsayısı 0.873 olarak hesaplanmıştır.

$\mathrm{Bu}$ analizlerden elde edilen bulguların doğru yorumlanmasına destek sağlamak amacıyla fen bilgisi öğretmenliği, sınıf öğretmenliği ve okul öncesi öğretmenliği ders programları, çevre konularını içeren derslerin olup olmadığına göre incelenmiş ve tablo-13'te verilmiştir (YÖK, 2012).

\section{Bulgular ve Yorumlar}

\subsection{Okul öncesi, sınıf ve fen bilgisi öğretmen adaylarının çevreye yönelik ortalama tutum} puanları ve çevresel tutum puanları arasındaki farklılıklara ait bulgular

Verilerin analizinde her öğrenciye ait bir çevresel tutum puanı elde edilmiştir. Daha sonra anabilim dallarına göre ortalamaları hesaplanmıştır. Ölçekten alınabilecek minimum puan 27, maksimum puan ise $135^{\prime}$ tir. Çevreye Yönelik Tutum Seviyelerinin Anabilim Dalı Değişkenine Göre Karşılaştırılması Tablo 1'de verilmektedir.

Tablo 1 Çevreye Yönelik Tutum Seviyelerinin Anabilim Dalı Değişkenine Göre Karşılaştırılması (One-Way ANOVA)

\begin{tabular}{lccc}
\hline Bölümler & $\mathrm{N}$ & $\overline{\mathrm{x}}$ & $\mathrm{S}$ \\
\hline Fen Bilgisi Öğretmenliği & 61 & 103.26 & 10.395 \\
Sinıf Öğretmenliği & 69 & 100.46 & 10.870 \\
Okul Öncesi Öğretmenliği & 31 & 92.87 & 22.692 \\
Toplam & 161 & 100.06 & 14.187 \\
\hline
\end{tabular}


Fen bilgisi öğretmen adaylarının ortalamada en yüksek çevresel tutum puanını $\left(\mathrm{x}_{\text {ort }}=103.26\right)$ aldıkları belirlenmiştir. Buna yakın bir değeri $\left(\mathrm{x}_{\text {ort }}=100.46\right)$ sınıf öğretmenliği adaylarının ve en düşük çevresel tutum puanını $\left(x_{\text {ort }}=92.87\right)$ okul öncesi öğretmenliği öğretmen adaylarının aldıkları görülmektedir. Farklı bölümlerdeki öğretmen adayları arasında çevresel tutum seviyeleri açısından anlamlı bir farklılık var mıdır, sorusuna cevap bulmak için yapılan analiz Tablo 2'de verilmiştir.

Tablo 2 Bağımsız Örneklemler (Fen Bilgisi Öğretmenliği, Sınıf Öğretmenliği, Okul Öncesi Öğretmenliği) İçin Tek-Faktörlü Varyans Analizi

\begin{tabular}{cccccc}
\hline Varyans Kaynağı & sd & $\begin{array}{c}\text { Kareler } \\
\text { Toplamı }\end{array}$ & $\begin{array}{c}\text { Kareler } \\
\text { Ortalamas1 }\end{array}$ & F & $\mathrm{p}$ \\
\hline Gruplar aras1 & 2 & 2238.932 & 1119.466 & 5.902 & $0.03^{*}$ \\
Grup içi & 158 & 29966.47 & 189.661 & & \\
Toplam & 160 & 32205.39 & & & \\
\hline
\end{tabular}

*Anlamll1ık düzeyi: $\mathrm{p}<0.05$

Tablo 2'deki sonuçlara göre, farklı bölümlerdeki öğretmen adayları arasında çevresel tutum seviyeleri açısından anlamlı bir fark bulunmuştur $(\mathrm{F}=5.902 ; \mathrm{p}<0.01)$. Farklılıkların hangi ikili gruptan kaynaklandığını gösteren çoklu karşılaştırma testi (Tukey testi) sonuçları Tablo 3' te verilmiştir.

Tablo 3 Çoklu Karşılaştırma (Tukey Testi) Sonuçları

\begin{tabular}{cccc}
\hline Bölümler & $\begin{array}{c}\text { Fen Bilgisi } \\
\text { Öğretmenliği }\end{array}$ & Sınıf Öğretmenliği & $\begin{array}{c}\text { Okul Öncesi } \\
\text { Öğretmenliği }\end{array}$ \\
\hline Fen Bilgisi Öğretmenliği & - & .481 & $.002^{*}$ \\
Sinıf Öğretmenliği & .481 & - & $.031^{*}$ \\
Okul Öncesi Öğretmenliği & $.002^{*}$ & $.031^{*}$ & - \\
\hline
\end{tabular}

*Anlamlılık düzeyi: $\mathrm{p}<0.05$

Tablo 3 incelendiğinde, fen bilgisi öğretmen adayları $\left(\mathrm{x}_{\text {ort }}=103.26\right)$ ile sinıf öğretmenliği öğretmen adaylarının $\left(\mathrm{x}_{\text {ort }}=100.46\right)$ çevresel tutum seviyeleri arasında anlamlı bir fark olmadığı sonucu ortaya çıkmıştır. Buna karşılık fen bilgisi-okul öncesi ve sınıf öğretmenliği-okul öncesi öğretmen adayları arasında anlamlı bir fark bulunmuştur. 


\subsection{Her bir anabilim dalının çevresel tutum puanlarının cinsiyete, sınıf değişkenine göre farklılıkları ve düşünce, davranış boyutları arasındaki ilişkileri}

Anabilim dalları, aldıkları ortalama çevresel tutum puanları göre burada incelenmiştir. Fen bilgisi öğretmen adaylarının tutum ölçeğinden aldıkları genel puanların ortalaması en yüksek olduğundan önce fen bilgisi öğretmen adaylarına ait bulgular, sonra sırasıyla sınıf öğretmenliği ve okul öncesi öğretmenliği adaylarına ait bulgular verilmiştir.

\subsection{Fen bilgisi öğretmen adaylarına ait bulgular}

Fen Bilgisi Öğretmen Adaylarının Çevreye Yönelik Tutum Seviyelerinin Cinsiyete Göre Karşılaştırılması Tablo 4'de, sınıflara göre karşılaştırılması ise tablo 5'te verilmektedir.

Tablo 4 Fen Bilgisi Öğretmen Adaylarının Çevreye Yönelik Tutum Seviyelerinin Cinsiyete Göre Karş1laştırılması

\begin{tabular}{|c|c|c|c|c|c|c|}
\hline Cinsiyet & $\mathrm{N}$ & $\overline{\mathrm{x}}$ & $\mathrm{S}$ & $\mathrm{sd}$ & $\mathrm{t}$ & $\mathrm{p}$ \\
\hline Erkek & 13 & 94.77 & 11.3 & & \multirow{2}{*}{3.645} & \multirow{2}{*}{$.001 *$} \\
\hline Kadın & 48 & 105.5 & 8.95 & 9 & & \\
\hline
\end{tabular}

*Anlaml1lık düzeyi: $\mathrm{p}<0.05$

Tablo 4 incelendiğinde fen bilgisi öğretmen adaylarının çevreye yönelik tutum ölçeği toplam puanları ortalaması, erkeklerde 94.77 ve standart sapmaları 11.3 olarak bulunmuş ve aynı ölçek uygulanan kadınların ise toplam puanları ortalaması ise 105.5 ve standart sapmaları 8.95 olarak hesaplanmıştır. Fen bilgisi öğretmen adaylarının çevreye yönelik tutum puanları arasında cinsiyete göre .05 düzeyinde kadınlar lehine anlamlı bir fark vardır.

Tablo 5 Fen Bilgisi Öğretmen Adaylarının Çevreye Yönelik Tutum Seviyelerinin Sınıflara Göre Karşılaştırılması

\begin{tabular}{ccccccc}
\hline Sinif & $\mathrm{N}$ & $\overline{\mathrm{x}}$ & $\mathrm{S}$ & $\mathrm{sd}$ & $\mathrm{t}$ & $\mathrm{p}$ \\
\hline 1.Sinif & 40 & 102.1 & 11.1 & & & \\
3.Sinif & 21 & 105.6 & 8.7 & & & \\
\hline
\end{tabular}

Anlamlılık düzeyi: $\mathrm{p}<0.05$ 
Tablo 5 incelendiğinde Fen bilgisi öğretmen adaylarının çevreye yönelik tutum ölçeği toplam puanları ortalaması, 1. sınıflarda 102.1 ve standart sapmaları 11.1 olarak bulunmuş ve aynı ölçek uygulanan 3. sınıfların ise toplam puanları ortalaması ise 105.6 ve standart sapmaları 8.7 olarak hesaplanmıştır. Fen Bilgisi öğretmen adaylarının çevreye yönelik tutum puanlarının sınıflara göre karşılaştırılmasından elde edilen sonuca göre, 1. sınıf ve 3.sınıf öğretmen adaylarının tutumları arasında anlamlı bir fark yoktur. Ancak ortalama puanlara bakıldığında, 3. sınıfların tutum puanlarının 1. sınıflara göre daha yüksek olduğu ortaya çıkmaktadır.

Fen Bilgisi Öğretmen Adaylarının Çevreye Yönelik Davranışları ile Düşünceleri Arasındaki İlişki Tablo 6'da verilmektedir.

Tablo 6 Fen Bilgisi Öğretmen Adaylarının Çevreye Yönelik Davranışları ile Düşünceleri Arasındaki İlişki

\begin{tabular}{lccc}
\hline & & Çevresel Davranış & Çevresel Düşünce \\
\hline Çevresel & $\mathrm{r}$ & 1 & .372 \\
Davranış & $\mathrm{P}$ & & .003 \\
& $\mathrm{~N}$ & 61 & 61 \\
\hline
\end{tabular}

Anlamlılık düzeyi: $\mathrm{p}<0,05$

Tablo 6'daki verilere göre, fen bilgisi öğretmen adaylarının çevreye yönelik davranışları ile düşünceleri arasında pozitif yönlü orta düzeyde anlamlı bir ilişki vardır.

\subsubsection{Sınıf Öğretmenliği Öğretmen Adaylarına Ait Bulgular}

Sınıf Öğretmenliği Öğretmen Adaylarının Çevreye Yönelik Tutum Seviyelerinin Cinsiyete Göre Karşılaştırılması Tablo 7’de verilmektedir.

Tablo 7 Sınıf Öğretmenliği Öğretmen Adaylarının Çevreye Yönelik Tutum Seviyelerinin Cinsiyete Göre Karşılaştırılması

\begin{tabular}{ccccccc}
\hline Cinsiyet & $\mathrm{N}$ & $\overline{\mathrm{x}}$ & $\mathrm{S}$ & $\mathrm{sd}$ & $\mathrm{t}$ & $\mathrm{p}$ \\
\hline Erkek & 48 & 104.33 & 8.319 & 67 & 5.281 & $.000^{*}$ \\
Kadın & 21 & 91.62 & 11.002 & & & \\
\hline
\end{tabular}

Anlamll1ık düzeyi: $\mathrm{p}<0,05$

Tablo 7 incelendiğinde sınıf öğretmenliği öğretmen adaylarının çevreye yönelik tutum ölçeği toplam puanları ortalaması, erkeklerde 104.33 ve standart sapmaları 8.319 olarak bulunmuş ve aynı ölçek uygulanan kadınların toplam puan ortalamaları ise 91.62 ve standart 
sapmaları 11.002 olarak hesaplanmıştır. Sınıf öğretmenliği öğretmen adaylarının çevreye yönelik tutum seviyelerinin cinsiyete göre karşılaştırılmasından elde edilen sonuca göre, erkek ve kadın öğretmen adaylarının tutumları arasında erkekler lehine anlamlı bir fark olduğu gözlemlenmiştir.

Sınıf öğretmenliği öğretmen adaylarının çevreye yönelik tutum seviyelerinin sınıflara göre karşılaştırılması tablo 8'de çevreye yönelik davranışları ile düşünceleri arasındaki ilişki ise tablo 9'da verilmiştir.

Tablo 8 Sınıf Öğretmenliği Öğretmen Adaylarının Çevreye Yönelik Tutum Seviyelerinin Sınıflara Göre Karşılaştırılması

\begin{tabular}{ccccccc}
\hline Sinif & $\mathrm{N}$ & $\overline{\mathrm{x}}$ & $\mathrm{S}$ & $\mathrm{sd}$ & $\mathrm{t}$ & $\mathrm{p}$ \\
\hline 1.Sinif & 48 & 104.33 & 8.319 & & & \\
3.Sinif & 21 & 91.62 & 11.00 & & 5.281 & $.000^{*}$ \\
\hline
\end{tabular}

Anlaml1l1k düzeyi: $\mathrm{p}<0,05$

Tablo 8 incelendiğinde sınıf öğretmenliği öğretmen adaylarının çevreye yönelik tutum ölçeği toplam puanları ortalaması, 1. sınıflarda 104.33 ve standart sapmaları 8.319 olarak bulunmuş ve aynı ölçek uygulanan 3. sınıfların ise toplam puanları ortalaması ise 91.62 ve standart sapmaları 11.002 olarak hesaplanmıştır. Her iki sınıfın da çevreye yönelik tutum ölçeği puan ortalamaları arasında .05 düzeyinde 1. sınıf öğretmen adayları lehine anlamlı bir fark olduğu belirlenmiştir.

Tablo 9: Sınıf Öğretmenliği Öğretmen Adaylarının Çevreye Yönelik Davranışları ile Düşünceleri Arasındaki İlişki

\begin{tabular}{lccc}
\hline & & Çevresel Davranış & Çevresel Düşünce \\
\hline Çevresel & Pearson Correlation & 1 & .136 \\
Davranış & Sig. (2-tailed) & & .264 \\
& $\mathrm{~N}$ & 69 & 69 \\
Çevresel & Pearson Correlation & .136 & 1 \\
Düşünce & Sig. (2-tailed) & .264 & \\
& $\mathrm{~N}$ & 69 & 69 \\
\hline
\end{tabular}

Anlaml1lık düzeyi: $\mathrm{p}<0.01$

Tablo 9'daki verilere göre, sınıf öğretmenliği öğretmen adaylarının çevreye yönelik davranışları ile düşünceleri arasında anlamlı bir ilişki bulunmamaktadır. 


\subsubsection{Okul Öncesi Öğretmen Adaylarına Ait Bulgular}

Okul öncesi öğretmen adaylarının çevreye yönelik tutum seviyelerinin cinsiyete göre karşılaştırılması tablo 10'da verilmektedir.

Tablo 10 Okul Öncesi Öğretmen Adaylarının Çevreye Yönelik Tutum Seviyelerinin Cinsiyete Göre Karşılaştırılması

\begin{tabular}{ccccccc}
\hline Cinsiyet & $\mathrm{N}$ & $\overline{\mathrm{x}}$ & $\mathrm{S}$ & $\mathrm{sd}$ & $\mathrm{t}$ & $\mathrm{p}$ \\
\hline Erkek & 10 & 97.40 & 18.494 & 29 & .761 & .453 \\
Kadın & 21 & 90.71 & 24.562 & & & \\
\hline
\end{tabular}

Tablo 10 incelendiğinde okul öncesi öğretmen adaylarının çevreye yönelik tutum ölçeği toplam puanları ortalaması, erkeklerde 97.40 ve standart sapmaları 18.494 olarak bulunmuş ve aynı ölçek uygulanan kadınların ise toplam puanları ortalaması ise 90.71 ve standart sapmaları 24.562 olarak hesaplanmıştır. Buna göre okul öncesi öğretmen adaylarının çevreye yönelik tutum seviyeleri arasında cinsiyete göre anlamlı bir farklılık yoktur.

Okul öncesi öğretmen adaylarının çevreye yönelik tutum seviyelerinin sınıflara göre karşılaştırılması tablo 11 'de, davranışları ile düşünceleri arasındaki ilişki tablo 12 'de verilmektedir.

Tablo 11 Okul Öncesi Öğretmen Adaylarının Çevreye Yönelik Tutum Seviyelerinin Sinıflara Göre Karşılaştırılması

\begin{tabular}{ccccccc}
\hline Sinif & $\mathrm{N}$ & $\overline{\mathrm{x}}$ & $\mathrm{S}$ & $\mathrm{sd}$ & $\mathrm{t}$ & $\mathrm{p}$ \\
\hline 1.Sinıf & 18 & 110.11 & 11.797 & 29 & 11.728 & $.000^{*}$ \\
3.Sinıf & 13 & 69.00 & 5.196 & & & \\
\hline
\end{tabular}

*Anlamlılık düzeyi: $\mathrm{p}<0.05$

Tablo 11 incelendiğinde okul öncesi öğretmen adaylarının çevreye yönelik tutum ölçeği toplam puanları ortalaması, 1. sınıflarda 110.11 ve standart sapmaları 11.797 olarak bulunmuş ve aynı ölçek uygulanan 3. sınıfların ise toplam puanları ortalaması ise 69.00 ve standart sapmaları 5.196 olarak hesaplanmıştır. Her iki sınıfın da çevreye yönelik tutum ölçeği puan ortalamaları arasında 1. sınıflar lehine anlamlı bir fark olduğu belirlenmiştir. 
Tablo 12 Okul Öncesi Öğretmen Adaylarının Çevreye Yönelik Davranışları ile Düşünceleri Arasındaki İlişki

\begin{tabular}{lccc}
\hline & & Çevresel Davranış & Çevresel Düşünce \\
\hline \multirow{3}{*}{ Çevresel Davranış } & Pearson Correlation & 1 & .684 \\
& Sig. (2-tailed) & & .000 \\
& $\mathrm{~N}$ & 31 & 31 \\
Çevresel Düşünce & Pearson Correlation & .684 & 1 \\
& Sig. (2-tailed) & .000 & 31 \\
\hline
\end{tabular}

*Anlamll1ık düzeyi: $\mathrm{p}<0.05$

Tablo 12'deki verilere göre, okul öncesi öğretmen adaylarının çevreye yönelik davranışları ile düşünceleri arasında pozitif yönlü orta düzeyde anlamlı bir ilişki vardır $(\mathrm{r}=0.684)$.

\section{3. Öğretmen adaylarının çevresel tutum düzeyleri ve lisansta aldıkları doğa ve çevre} içerikli dersler

İlköğretim bölümündeki anabilim dallarının (okul öncesi öğretmenliği, sınıf öğretmenliği, fen bilgisi öğretmenliği) çevre konularını içeren dersleri ve ait oldukları dönemler Tablo 13'de verilmektedir.

Tablo 13: Anabilim Dallarına Göre Çevre İçerikli Dersler ve Dönemleri

\begin{tabular}{lll} 
Okul Öncesi Öğretmenliği & Sinff Öğretmenliği & Fen Bilgisi Öğretmenliği \\
\hline & 1.dönem: Genel Biyoloji & \\
& 3.dönem: Çevre Eğitimi & 3.dönem: Genel Biyoloji I \\
5.dönem: Fen Eğitimi & & 5.dönem: Fen Bilgisi Laboratuar Uygulamaları I \\
\hline & 6.dönem: Çevre Bilimi \\
& 7.dönem:Biyolojide Özel Konular \\
& Evrim \\
& Çevre Eğitimi (seçmeli) \\
\hline
\end{tabular}

Tablodan görüldüğü gibi okul öncesi öğretmenliğine ait çevre konularını içeren sadece Fen Eğitimi dersi bulunmaktadır. Çevre ile ilgili herhangi bir seçmeli ders programlarında yer almamaktadır. Sınıf öğretmenliğinde 3. dönemde Çevre Eğitimi dersi bulunmakta, bu yıllara ait seçmeli ders bulunmamaktadır. Fen bilgisi öğretmenliğinde 6.dönemde Çevre Bilimi dersi dahil olmak üzere içeriğinde az veya çok çevre konularının yer aldığı 6 farklı ders bulunmaktadir. 


\section{Sonuç ve Tartışma}

UNESCO (2005) tarafından hazırlanan "Sürdürülebilirlik Açısından Öğretmen Eğitimini Yeniden Planlama Önerileri ve Rehberi”ne göre Sürdürülebilir Kalkınma İçin Eğitim, bilgiyi pasif olarak alma ve konuları anlamaktan çok, bu konuda beceri, tutum, değer ve anlayış geliştirmekle sağlanabilir. Bu nedenle okul öncesi ve ilköğretimde çevre eğitimi verecek olan öğretmen adaylarının çevreye karşı tutum ve davranışlarının yüksek düzeyde olması beklenmektedir.

Çalışmada yer alan öğretmen adaylarının en yüksek ortalama çevresel tutum puanı 103.26 ile fen bilgisi öğretmen adaylarının, en düşük ortalama çevresel tutum puanının 92.87 ile okul öncesi öğretmen adaylarının olduğu tespit edilmiştir. Sınıf öğretmenliği öğretmen adaylarının ortalama çevresel tutum puanının ise 100.46 olduğu belirlenmiştir. Üç farklı anabilim dalı öğretmen adayları çevresel tutum seviyeleri açısından değerlendirildiğinde, fen bilgisi öğretmen adayları ile sınıf öğretmenliği öğretmen adayları arasında anlamlı bir farkın olmadığı buna karşılık fen bilgisi-okul öncesi ve sınıf öğretmenliği-okul öncesi öğretmen adayları arasında anlamlı bir farkın olduğu tespit edilmiştir. Yapılan bu çalışma ile öğretmen adaylarından beklenen tutum puanlarının yeterli olmadığı görülmektedir. Şahin ve ark. (2004) yüksek öğretimde çevre eğitiminin yeterince verilemediğini vurgulamışlardır.

Öğretmen adaylarının çevresel tutum seviyeleri cinsiyet açısından değerlendirildiğinde fen bilgisi öğretmen adayları içinde kadınların çevresel tutum seviyelerinin erkeklere göre daha olumlu olduğu, sınıf öğretmenliği öğretmen adayları içinde erkeklerin çevresel tutum seviyelerinin kadınlara göre daha olumlu olduğu, okul öncesi öğretmen adaylarında ise cinsiyete bağlı tutumlarında anlamlı bir farkın olmadığı belirlenmiştir. Şama (2003)'nın üniversite öğrencileri üzerinde yaptığı çalışmada; kız öğrencilerin çevre tutumlarının erkeklerden daha olumlu olduğu sonucu ortaya çıkmıştır. Bu çalışmamızda kadın ve erkekler arasında örnekleme göre değişen bir durum söz konusudur. Bu konuda cinsiyet belirleyici bir özellik taşımamaktadır.

Öğretmen adaylarının çevresel tutum seviyeleri sınıflara göre değerlendirildiğinde fen bilgisi 3. sınıfta olan öğrencilerin çevreye yönelik tutum seviyelerinin 1. sınıfta olan öğrencilerden daha olumlu olduğu belirlenmiştir. $\mathrm{Bu}$ durum beklenen bir durumdur. Öğretmen adaylarının üniversitede aldıkları derslerin ve eğitimin etkisi olduğu söylenebilir. Çalışma bulgularından elde edilen, beklenmeyen bir durum ise, sınıf öğretmenliği ve okul öncesi öğretmen adaylarının 1. sınıfta olan öğretmen adaylarının çevreye yönelik tutum seviyelerinin 3. sınıfta olan öğretmen adaylarından daha olumlu olmasıdır. Bu çalışma 
boylamsal bir çalışma olmadığından üniversitede aldıkları eğitim ve öğretim hakkında kesin bir şey söylemek mümkün olmamakla birlikte sınıf öğretmenliği ve okul öncesi öğretmenliği 3. sınıf öğretmen adaylarının çevresel puanlarının oldukça düşük olduğu (okul öncesi ort.puanı: 69.00, sınıf öğretmenliği ort. puan1: 91.62) kesindir.

Öğretmen adaylarının tutumlarının düşünce ve davranış boyutları karşılaştırıldığında düşünce boyutunun, davranış boyutundan daha üstün olduğu görülmüştür. Bu durum düşünce açısından değerlendirildiğinde bireylerin kendi görüşlerine göre çevreci oldukları ama düşündüklerini uygulamaya gelince aynı başarıyı sergileyemediklerini göstermektedir. Ayrıca fen bilgisi öğretmen adaylarının ve okul öncesi öğretmen adaylarının çevreye yönelik davranış ve düşünceleri arasında pozitif yönlü orta düzeyde bir ilişkinin olduğu tespit edilmiştir. Sınıf öğretmenliği öğretmen adaylarının ise çevreye yönelik davranış ve düşünceleri arasında anlamlı bir ilişki bulunamamıştır.

Tüm öğretmen adaylarının birbirlerinden biraz farkları olsa da çevreye karşı olumlu düşünce ve davranışları hem kendileri hem de yetiştirecek oldukları gelecek nesiller için daha iyi bir şekilde geliştirilmesi gerektiği ortadadır. Ancak programdaki dersler incelendiğinde (tablo 13) okul öncesi öğretmen adaylarının lisans seviyesinde çevre içerikli bir dersleri bulunmadığ1 görülmektedir. Sınıf öğretmenliği öğretmen adaylarının 3. döneme ait bir Çevre Eğitimi dersi mevcuttur. Sınıf öğretmenliği ve okul öncesi öğretmenliği 3.sınıf öğrencilerinin bu düşük çevresel tutum puanlarıyla öğretmen olacakları (oldukları) düşünülebilir. Çünkü okul öncesinde böyle bir ders mevcut değil, sınıf öğretmenliği içinde 3. dönemden sonra böyle bir ders bulunmamaktadır. Fen bilgisi öğretmenliği anabilim dalı bu konuda daha iyi bir durumda görülmektedir. Ayrıca bu uygulamanın yapıldığı 3. sınıf öğretmen adayları eğitimlerinin devamında, programlarında bulunan çevre içerikli dersler alacaklarından (tablo 13) bilgi, düşünce ve çevresel tutumlarında daha fazla artış olabileceği düşünülebilir.

Okul öncesi anabilim dalı programına doğa ve çevre içerikli derslerin eklenmesinin bu konuda çok yararlı olacağı düşülmektedir. Sınıf öğretmenliği anabilim dalı programında var olan derse ek olarak seçmeli çevre içerikli dersler konabilir. Her üç anabilim dalı öğretmen adaylarındaki çevresel tutumu geliştirmek için çevre eğitiminde otantik öğretim yaklaşımları, uygulamalı çevre eğitimleri, doğa gezileri gibi aktif katılım becerisi geliştiren tekniklerin kullanılması muhtemelen çevre ve doğa açısından daha olumlu sonuçlar ortaya çıkarabilir.

Lisans düzeyinde ilköğretim bölümünde, az sayıdaki çevre ile ilişkili derslerle, çevresel tutumu yüksek bireyler yetiştirmeyi düşünmek gerçeklikten biraz uzak görünmektedir. Bu nedenle çevre konusu sadece çevre içerikli derslere bırakılmamalı, diğer 
tüm derslerde de zaman zaman ve değişik konularla ele alınmalıdır. Bilimsel doğasından dolayı disiplinler arası bir özellik göster çevre eğitimi bu uygulamalar için oldukça uygundur. $\mathrm{Bu}$ özelliğinde dolayı farklı alanlarda çalışan öğretim üyelerine ve öğretmen adaylarına farklı çevre konularında zaman zaman çevre eğitimleri verilerek çevre konularına dikkat çekilmeli ve derslerinde çevre konularından bahsetmelerine zemin hazırlanmalıdır.

Çevre eğitimi hayat boyu sürmesi gereken bir etkinliktir. Sadece örgün eğitim şeklinde verilmesi yeterli olmayabilir. Bu nedenle derslerin eksik kaldığı durumlarda ve devamlılığ sağlamak amacıyla öğretim üyeleri tarafından öğretmen adaylarının çevre ile ilgili sivil toplum kuruluşlarında görev almaları önerilebilir ve bu konularda öğretmen adayları desteklenmelidir. Böylece bireylerin katılım becerilerinin ve dolayısıyla tutum seviyelerinin oldukça iyi derecede arttırılması sağlanabilir.

\section{Kaynakça}

Alım, M. (2006). Avrupa Birliği Sürecinde Türkiye'de Çevre ve İlköğretimde Çevre Eğitimi. Kastomonu Ĕ̆itim Dergisi, (14)2, 599-616.

Aydoğdu, M. \& Gezer, K. (Eds.). (2006). Çevre Bilimi. (1.baskı). Ankara: Anı Yayıncılık.

Aydın, O. (2000). Davranış Bilimlerine Giriş. Eskişehir: Anadolu Üniversitesi Yayınları No:1027.332.

Ayvaz, Z. (1998). Çevre Eğitimine Giriş. İzmir: Ç evre Eğitimi Merkezi Yayınları.

Bozkurt, O., Salman- Akın, B. \& Uşak, M. (2004). İlköğretim 6., 7. ve 8. Sınıf öğrencilerinin "Erozyon” Hakkındaki Ön Bilgilerinin ve Kavram Yanılgılarının Tespiti. Gazi Üniversitesi Kırşehir Eğitim Fakültesi Dergisi, 5, 277-283.

Büyüköztürk, Ş., Çakmak, E.K., Akgün, Ö.E., Karadeniz, Ş. \& Demirel, F. (2008). Bilimsel Araştırma Yöntemleri. Ankara: Pegem Akademi Yayıncılık.

Carson, R. (1962). Silent Spring. Güler, Ç.(2004) Palme Yayıncılık ISBN:9758982079

Cordes, C. \& Miller, E. (Eds.). (1999). Fool's Gold: A Critical Look at Computers in Childhood. Alliance for Childhood. www.alliancefor childhood.org/projects/computers /computers reports fools_gold contents.htm

Çepel, N. (2003). Ekolojik Sorunlar ve Çözümleri. (2.bask1). Ankara: TÜBİTAK Popüler Bilim Kitapları.

De Haan, G. (1991). Ökologie-Handbuch Grandschule. Weinheim und Basel.

Eagles, P. F., \& Demare, R. (1999). Factors influencing children's environmental attitudes. Journal of Environmental Education, 30(4), 33-37. 
Farmer, J., Knapp, D. \& Benton, G. M. (2007). An Elementary School Environmental

Education Field Trip: Long-Term Effects on Ecological and Environmental Knowledge and Attitude Development. The Journal of Environmental Education, 38(3), 33-42.

Gülay, H. \& Ekici, G. (2010). MEB Okul Öncesi Eğitim Programının Çevre Eğitimi Açısından Analizi. Türk Fen Eğitimi Dergisi.7(1), 74-84.

Hungerford, H.R., Volk, T.L. and Ramsey, J.M, (1994). A Prototype environmental Education Curriculum forthe Middle School. UNESCO-UNEP-IEEP: Environmental Education Series (29).

IEEP (1994). An Environmental Education Curriculum for Pre-Service Education of Secondary Level Teacher. UNESCO-UNEP-IEEP: Environmental Education Series (43).

ICEE (Intergovernmental Conference on Environmental Education) (1977). Tbilisi http://unesdoc.unesco.org

Kaiser, F., Ranney, M., Hartig, T. \& Bowler, P. A. (1999). Ecological behavior, environmental attitude, and feelings of responsibility for the environment. European Psychologist, 4, 59-74.

Keleş, Ö., Uzun, N. \& Uzun, F.V. (2010). Öğretmen Adaylarının Çevre Bilinci, Çevresel Tutum, Düşünce ve Davranışlarının Doğa Eğitimi Projesine Bağlı Değişimi ve Kalıcılığının Değerlendirilmesi. Elektronik Sosyal Bilimler Dergisi, (9)32, 384-401.

Metin, M. (2010), A study on developing a general attitude scale about environmental issues for students in different grade levels. Asia-Pacific Forum on Science Learning and Teaching, (11) 2, 1-19.

Özgüven, A. (2004). Insan ve Çevre İlişkilerine Giriş. Eskişehir: Anadolu Üniversitesi Yayınları No: 1027.332.

Pooley, J.A., O’Connor, M. (2000). Environmental Education and Attitudes: Emotions and beliefs are what is needed. Environment and Behavior. 32(5): 711-723.

Şafaklı, O.V. (2012). A research on environmental attitudes in Northern Cyprus. African Journal of Agricultural Research Vol. 7(6), 1002-1010.

Şahin, N., Cerrah, L., Saka, A. \& Şahin, B. (2004). Yüksek Öğretimde Öğrenci Merkezli Çevre Eğitimi Dersine Yönelik Bir Uygulama. Gazi Eğitim Fakültesi Dergisi, (24) 3, 113-128.

Şama, E. (2003).Öğretmen Adaylarının Çevre Sorunlarına Yönelik Tutumları. Gazi Eğitim 
Fakültesi Dergisi. 23(2), 99-110.

Schumacher, F. (1973). Small is Beautiful Çeviri: Özel, M. (1995) Küçük Güzeldir. İstanbul: Martı Yayınevi

Şimşekli Y. (2004). Çevre Bilincinin Geliştirilmesine Yönelik Çevre Eğitimi Etkinliklerine İlköğretim Okullarının Duyarlılığı. Uludă̆ Üniversitesi Eğitim Fakültesi Dergisi, XVII, (1), 83-92.

Tanrıverdi, B. (2009). Sürdürülebilir Çevre Eğitimi Açısından İlköğretim Programlarının

Değerlendirilmesi. Eğitim ve Bilim, (34) 151, 89-103.

Thompson, S.C.G. \& Barton, M.A. (1994). Ecocentric and anthropocentric attitudes toward the environment. Journal of Environmental Pschology, 14, 149-157.

Tuncer, G., Ertepinar, H., Tekkaya, C., \& Sungur, S. (2005). Environmental attitudes of young people in Turkey: Effects of school type and gender. Environmental Education Research, 11(2), 215-233.

Uluçınar Sağır, Ş., Asalan, O. \& Cansaran, A. (2008). ilköğretim Öğrencilerinin Çevre Bilgisi ve Çevre Tutumlarının Farklı Değişkenler Açısından İncelenmesi. Elementary Education Online, 7(2), 496-511.

UNEP (1972).

http://www.unep.org/Documents.Multilingual/Default.asp?documentid=97\&arti cleid $=1503$

UNESCO- UNEP. (1987). Environmental Education and Training. Moskova.

UNESCO (2005). http://www.unesco.org/education/justpublished desd2009.pdf

Uzun, N. \& Sağlam, N. (2006). Orta Öğretim Öğrencileri için Çevresel Tutum Ölçeği Geliştirme ve Geçerliliği. Hacettepe Üniversitesi Eğitim Fakültesi Dergisi, 30, 240-250.

UNEP (2012). http://www.unep.org/documents.multilingual/default.asp?documentid=52

Ünal, S., Mançuhan, E., \& Sayar, A.A. (2001). Çevre: Bilinci, bilgisi ve eğitimi. İstanbul: Marmara Üniversitesi Yayın No: 680.

Worsley, A., \& Skrzypiec, G. (1998). Environmental attitudes of senior secondary school students in South Australia. Global Environmental Changes, 8, 209-255.

Yücel, A.S. \& Morgil, S.F. (1999). Çevre Eğitiminin Geliştirilmesi. BAÜ Fen Bilimleri Enstitüsü Dergisi, 1, 76-89.

YÖK (2012). http://www.yok.gov.tr/component/option,com 